\title{
ARCHITECTURAL AND ENGINEERING DESIGN CRITERIA FOR EARTHQUAKE RESISTANT MASONRY INFILLED RC FRAMES CONTAINING OPENINGS
}

\author{
Davorin Penava ${ }^{1 *}$, Daniel Alejandro Arciniega Larrea ${ }^{2}$, Filip Anić ${ }^{1}$, Lars Abrahamczyk ${ }^{2}$ \\ ${ }^{1}$ Josip Juraj Strossmayer University of Osijek, Faculty of Civil Engineering and Architecture Osijek, Vladimira \\ Preloga 3, 31000 Osijek, Croatia \\ ${ }^{2}$ Bauhaus Universität Weimar, Earthquake Damage Analysis Center (EDAC), Marienstraße 13B, 99423 \\ Weimar, Germany \\ *E-mail of corresponding author: davorin.penava@gfos.hr
}

\begin{abstract}
In earthquake resistant design of RC frame structures, the definition of masonry infilled frame is often split between reinforced concrete and the masonry structures. However, it is known that the frame elements and the masonry wall work as a coupled system. Additionally, a dedicate chapter for the definitions of openings size, quantity and position is missing. The definition of a full, partial or non-masonry infilled frame with opening is not establish in engineering and architectural codes; rather, recommendations are given. A competent masonry infilled frame with openings would mean to correlate the architectural and engineering concepts as to define an engineered or non-engineered infilled wall. Likewise, certain boundaries should be established using both the architectural and engineering concepts to relate the importance of illumination and air ventilation product of the openings and masonry infilled frame failure patterns.
\end{abstract}

Keywords: Structural Masonry, Masonry Infilled Frames, Openings, Earthquake Engineering Design, Architectural Design

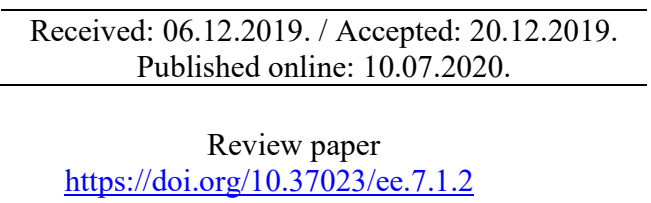

\section{INTRODUCTION}

Throughout the world, reinforced concrete (RC) frames are common load-bearing systems of multi-storey buildings. In order to form spaces within such buildings, various kinds of infill walls are introduced by the architectural design. Commonly, infill walls contain one or more openings in order to allow communication between the spaces and/or the incursion of light.

During an earthquake event, such aforementioned buildings are considered to have a higher degree of seismic vulnerability (Schwarz et al. 2015). Furthermore, European seismic codes (CEN 2004) regard infill walls as non-load-bearing elements. This, however, was a simplification made by code creators, as at the time, there was little to no knowledge about infill-frame interaction. As many researchers found, infill does influence the stiffness, crack and yield patterns, failure modes etc. (Asteris et al. 2013; Di Trapani et al. 2015; Dowrick 2009; Penava et al. 2018). Likewise, openings in terms of their type, size, position and combination have their share influencing the behaviour (Akhoundi et al. 2016; Cetisli 2015; Kakaletsis \& Karayannis 2008; Sigmund \& Penava 2014; Wang 2017).

Therefore, there is a need to blend architectural practice and engineer's demands. This paper lays out the principles of opening size and position within unreinforced, masonry (URM) infill walls in order to comprehend such a demand.

\section{CLARIFICATION OF MASONRY INFILL WALL DESCRITPIONS IN EARTHQUAKE CODE STANDARDS}

There are certain differences in description and structural design of infill walls between various seismic codes. A short summarisation of the code's provisions with respect to the masonry infill walls are presented in further sub-sections.

\subsection{Eurocode 8 (EN 1998-1-1)}

European seismic standard, Eurocode 8, i.e. EN 1998-1-1 (CEN 2004), regard a frame or frame equivalent dual concrete systems (DCS) of high ductility (DCH) with interacting non-engineered masonry infills, if it satisfies the following conditions: a) Infill is constructed after the concrete in the frame hardens; b) Masonry infill is in the contact with the surrounding frame (i.e. without special separation joints, gaps, etc.), but without structural 
connection to it (through ties, belts, posts or shear connectors); c) They are considered in principle as non-structural elements.

Again, Eurocode 8, i.e. EN 1998-1-1 (CEN 2004), states that infills can be neglected. However, if engineered masonry infills are a part of the seismic resistant structural system, analysis and design should be carried out in accordance with the criteria and rules given in "Rules for simple masonry buildings" for confined masonry.

As a principle, the consequences of irregularity in plan and elevation produced by the infills should be considered in the design. High uncertainties related to the behaviour of the infills should be accounted for. Those are, namely, the variability of their mechanical properties and of their attachment to the surrounding frame, their possible modification during the use of the building, as well as their non-uniform degree of damage suffered during the earthquake itself. Also, designer should account for possible adverse local effects due to the frame-infill interaction (e.g. shear failure of columns under shear forces induced by the diagonal strut action of infills).

Strongly irregular, unsymmetrical or non-uniform arrangements of infills in plan should be avoided (considering the extent of openings and perforations in infill panels). Infill panels with more than one significant opening or perforation (e.g. a door and a window, etc.) should be disregarded in models for analyses.

Furthermore, if there are considerable irregularities in elevation (e.g. drastic reduction of infills in one or more storeys compared to the others); in principle, the seismic action effects in the vertical elements of the respective storeys should be increased. For the frame or DCS belonging to all ductility classes, DCL (low), M (medium) or $\mathrm{H}$ (high), except in cases of low seismicity, appropriate measures should be taken to avoid brittle failure and premature disintegration of the infill walls (in particular of masonry panels with openings or of friable materials), as well as the partial or total out-of-plane collapse of slender masonry panels. Particular attention should be addressed to masonry panels with a slenderness ratio (ratio of the smaller of length or height to thickness) of greater than 15 .

Examples of measures for the improvement of both in-plane and out-of-plane integrity and behaviour, include: a) light wire meshes well anchored on one face of the wall; b) wall ties fixed to the columns and cast into the bedding planes of the masonry; c) concrete posts and belts across the panels and through the full thickness of the wall. If there are large openings or perforations in any of the infill panels, their edges should be trimmed with belts and posts.

\subsection{Federal Emergency Management Agency (FEMA)}

In comparison with Eurocode 8 provision (CEN 2004), FEMA 356 (ASCE 2000) has a different approach in its requirements. It states that $\mathrm{RC}$ frames with masonry infills should be constructed in such a way that the infill and the concrete frame interact when subjected to vertical and lateral loads. The columns act as vertical chords, beam as horizontal ties and the infill as an equivalent diagonal strut. On one hand; FEMA 306 (ATC, 1998) states that, to be effective at resisting in-plane lateral loads, the infill must be in contact with the surrounding frame. On the other hand; FEMA 749 (FEMA P-749 2010) states that ordinary concrete and ordinary masonry bearing wall systems are not permitted in Seismic Design Categories D or higher.

\subsection{National Building Code of Canada (NBC)}

National Building Codes of Canada (NRCC 2010) states that masonry infill walls are to be treated as shear walls and should be designed to resist both in-plane and out-of-plane loads along with any vertical loads. The increased stiffness of lateral load-resisting elements that consist of masonry infill shear walls working with the surrounding frame, should be considered when distributing the applied loads to these elements. When diagonal strut is used to model the infill shear wall a truss model can be used to design in-plane behaviour, and arching action model for the out-of-plane behaviour.

The code offers three possible design and construction approaches for infill walls:

1. Participating infill (diagonal strut approach) - when there are no openings or gaps between the masonry infill and the surrounding frame, but the infill is not tied or bonded to the frame, the infill should be modelled as a diagonal strut. Where openings or gaps exist, the designer must show through experimental testing or special investigations that the diagonal strut action can be formed and all other structural requirements for the infill shear walls can be developed.

2. Frame and infill composite action - when the infill shear wall is tied and bonded to the frame to create a composite shear wall, where the infill forms the web and the columns of the frame form the flanges of the shear wall.

3. Isolated infill - it is also possible to design an isolated infill panel, which is separated from the frame structure by a gap created by vertical movement joints along the ends and a horizontal movement joint under the floor above or beam. In that case, masonry infill is a non-load-bearing wall and cannot be treated as a shear wall. Restraints must be provided at the top of the wall to ensure stability for out of-plane seismic forces. 


\subsection{The New Zealand Standard (NZS)}

The New Zealand Standard NZS 4230:2004 (NZSI 2004) states that the infill panels should be designed to resist all actions resulting from in-plane loads and face loads (out-of-plane, i.e. wind or earthquake). Masonry infills should be designed as elastic structures and detailed to ensure that infill and frame act together in full composite action as a shear wall. Structural infill panel reinforcement should be connected to adjacent beams and columns to ensure that composite action. Infill panels with openings should be subject to special study to ensure diagonal bracing action can be obtained, and to investigate the effects of structural modification caused by the openings. Infill panels separated from the structural system are considered to be partitions.

\section{RESTRICTIONS IMPOSED TO OPENING SIZES AND POSITIONS FROM ARCHITECTURAL AND ENGINEERING CRITERIA}

The openings in this section are referred to doors and windows, which positions and sizes are limited by architectural and engineering concepts.

\subsection{Architectural design concepts}

The analysis starts with the definition of window and door given by architectural concept required for a proper living style. Neufert and Neufert (2012) in the same reference, provide a mesh of recommended sizes for windows and doors which are connected with the masonry modulation.

\subsubsection{Masonry walls}

Perimeter ties (column ties and lintel) are required for the transfer of horizontal forces over all external and transverse walls in buildings with more than two full storeys or more than $18 \mathrm{~m}$ in length and walls with many or large openings under the floor slab. This rule applies when the sum of the opening area is higher than $60 \%$ of the surface, or is higher than $40 \%$ of the surface length, or these openings have a width larger than $2 / 3$ of the height of the floor.

Table 1 presents the recommended thickness, separation and longitude for load-bearing walls defined by Neufert and Neufert (2012).

Table 1. Thickness, separation and longitude of the load-bearing walls

\begin{tabular}{|c|c|c|c|c|}
\hline \multicolumn{2}{|c|}{ Wall thickness $(\mathrm{cm})$} & Clear wall height $(\mathrm{m})$ & Separation $(\mathrm{m})$ & Longitude \\
\hline$\geq 15.50$ & $<17.50$ & \multirow{2}{*}{$\leq 3.25$} & $\leq 4.50$ & \multirow{3}{*}{$\geq 1 / 5$ of the floor height } \\
\hline$\geq 17.50$ & $<24.00$ & & $\leq 6.00$ & \\
\hline $\begin{array}{r}\geq 24.00 \\
\geq 3\end{array}$ & $<30.00$ & $\begin{aligned} & \geq 3.50 \\
\leq 5.00 & \text { or } 12 t\end{aligned}$ & $\leq 8.00$ & \\
\hline
\end{tabular}

\subsubsection{Window openings}

Window in itself, has an essential function apart from just sealing the opening. It controls the level of natural lighting, the supply and extraction of air and the view outside. The size and location of windows in rooms, in addition to the requirements under building regulations and the rules for daylight in interiors are determined above all by architectural considerations. Important factors are: the location in the wall, with internal windows emphasizing the wall depth and external windows allowing the wall to present as a surface; aspect ratio; the ratio of construction thickness to glass area (visible frame, casements and possibly glazing bar widths); and the relationship to other façade elements (which is often neglected when replacing windows). The type of opening determines the functional quality as a ventilation element.

In residential buildings the minimum requirement for structural window apertures in occupied rooms is specified by the building regulations as $1 / 8$ or $1 / 10$ of the plan area of the room. For rooms with dimensions corresponding to those of residential rooms, the minimum height of the glass area is $1.3 \mathrm{~m}$.

Neufert and Neufert (2012) provide guidelines for structural window opening sizes, as described in Figure 1. The relative length and height in Figure 1 are a multiple of the unit of measure, e.g. for the unit of $125 \mathrm{~mm}$ and window opening $9 \times 11=(9 \times 125) \times(11 \times 125)=1125 \times 1375 \mathrm{~mm}$.

For example, in the case of the living areas which are categorized into shared rooms (living and dining rooms, kitchens) and individual (private) rooms for one or two people (parents' bedroom, children's room, guest room), the individual room can be used with a flexible range of functions. It has an area of approximate $13 \mathrm{~m}^{2}$, including movement areas suitable for a wheelchair and possible extension onto an open balcony (Figure 2) and the bedrooms with minimal space of approximate $13 \mathrm{~m}^{2}$ (as parent's room or twin bedroom) and approximate $8 \mathrm{~m}^{2}$ (single room). 


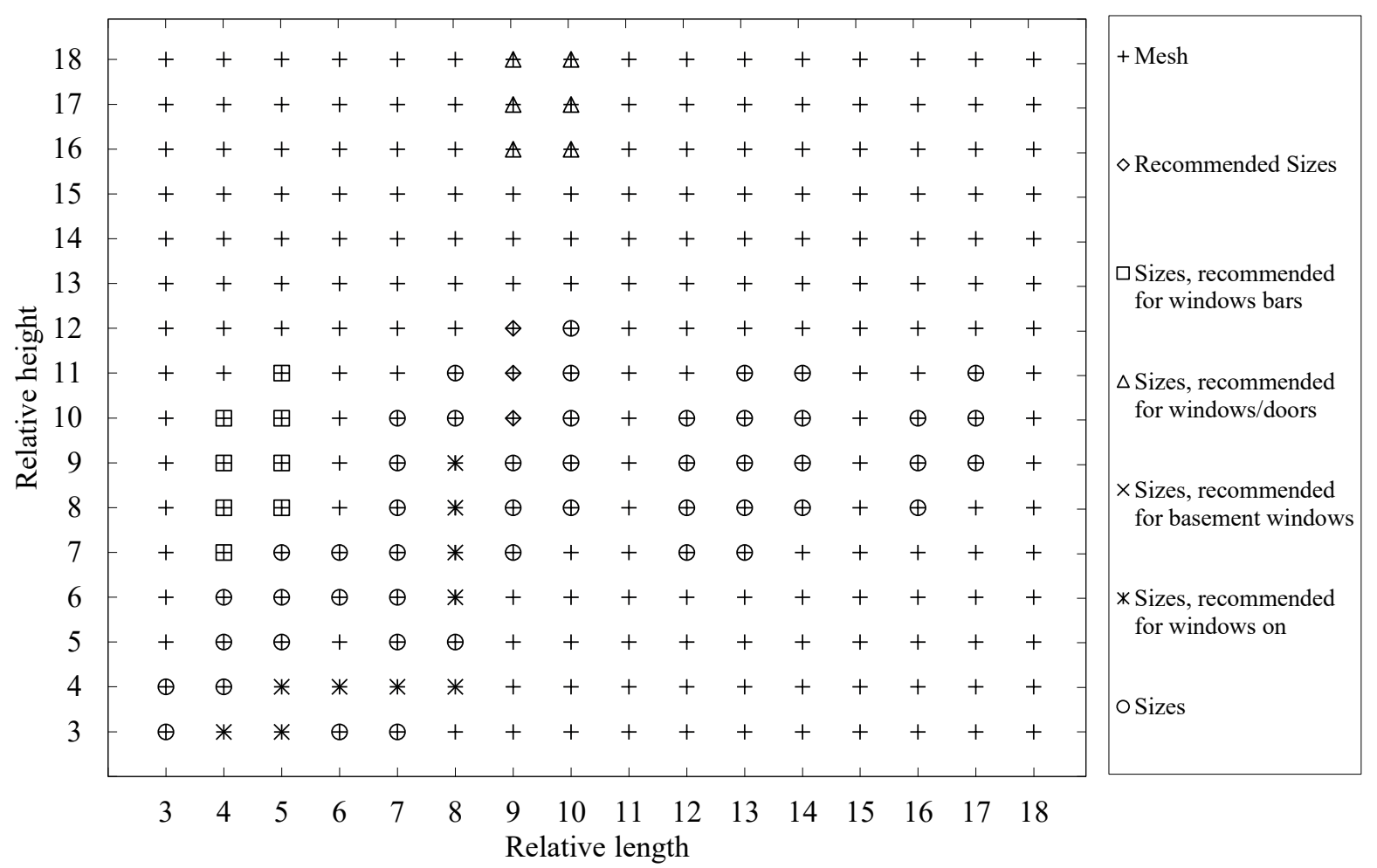

Figure 1. Guideline sizes for structural window openings (Neufert \& Neufert 2012)

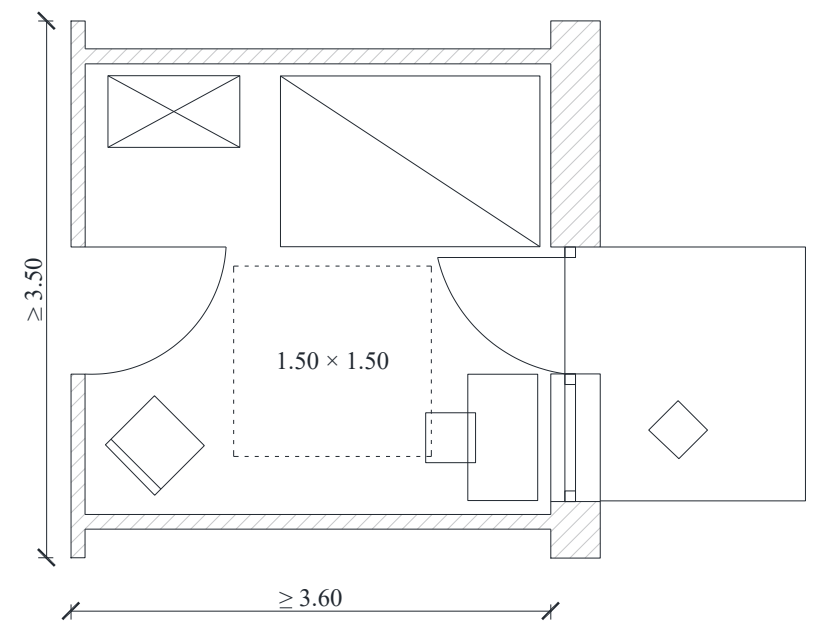

Figure 2. Individual room (Neufert \& Neufert 2012)

\subsubsection{Door openings}

Doors must be sensibly arranged as unfavourably distributed or unnecessary doors impair rooms use, or cause difficulties that can lead to the loss of storage places. The width of a door depends on the intended use and the type of room to be accessed. Minimum clear width for walking through is $55 \mathrm{~cm}$, but a minimum dimension for disability-friendly building and marked heights for glass door is $90 \mathrm{~cm}$.

Dimension of wall openings for doors are standard modular dimensions. If, in exceptional cases, different dimensions are required; then their modular dimensions should be whole multiples of $125 \mathrm{~mm}$ (100 m according to British Standards (BSI 2015). A wall opening with $875 \mathrm{~mm}$ width and $2000 \mathrm{~mm}$ of height (modular dimensions) can be described as: wall opening DIN $18100-875 \times 2000$. In order to determine the door width, the frame detail has to be considered in the calculation of the structural opening, as some variants offer interesting creative possibilities of reducing the clear opening width by more than standard cased doors on the account of the thickness of their construction.

Neufert and Neufert (2012) provide modular wall opening sizes for structural door openings, which are described in the Figure 3. 


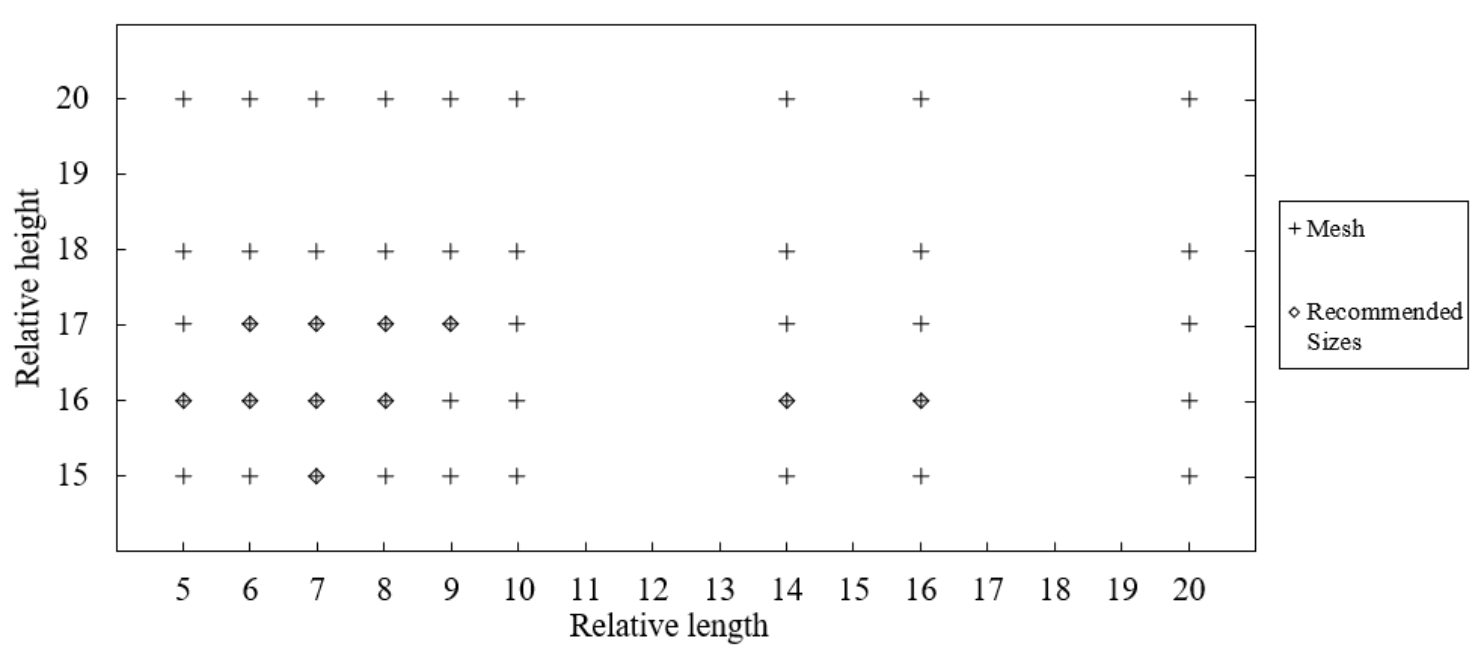

Figure 3. Modular wall openings (Neufert \& Neufert 2012)

\subsection{Engineering design concepts}

Eurocode 6 (CEN 2005) and 8 (CEN 2004) provide guidelines to follow the effects of masonry structures but do not define the masonry infilled RC frames. A stiffening wall is a wall that is perpendicular to another. Its purpose is to give support against lateral forces or to resist buckling, and by doing so, it provides extra stability to the building. Since there is not a definition of masonry infilled RC frame, the definition of a stiffening wall is used through this paper.

\subsubsection{Eurocode 6 (EN 1996)}

Eurocode 6 (CEN 2005) provides no rules regarding the openings, however, it has certain recommendations. A recommendation of the walls' minimum length between openings is given by the analysis of structural members subjected to vertical loading and is presented in the Figure 4, where the stiffening wall should extend a distance of at least $1 / 5$ of the storey height beyond each opening.

The recommendation defines the effective height of masonry walls rather than the wall openings. For example, walls with openings that have a clear height of more than $1 / 4$ of the clear height of the wall or a clear width of more than $1 / 4$ of the wall length or an area of more than $1 / 10$ of the total area of the wall, should be considered as having a free edge at the opening for the purposes of determining the effective height.

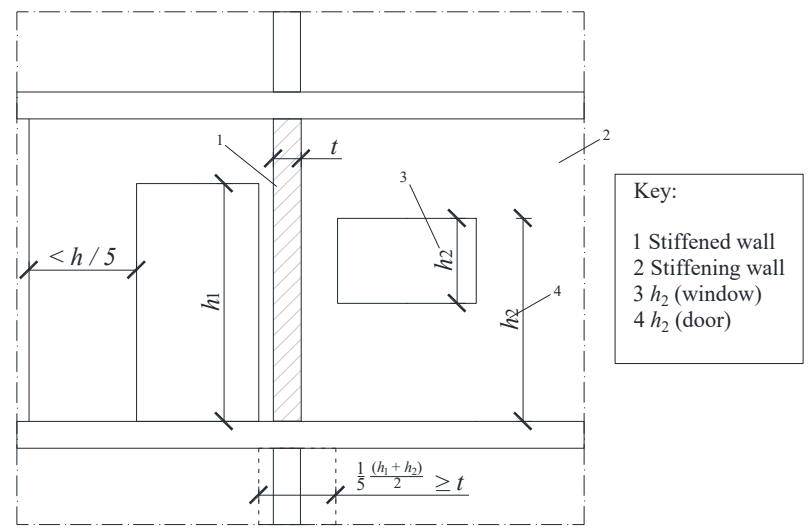

Figure 4. Minimum length of stiffening wall with openings

\subsubsection{Eurocode 8 (EN 1998)}

Eurocode 8 (CEN 2004) lays out specific rules for masonry buildings. It provides general design criteria and construction rules where shear walls should conform to certain geometric requirements. The ratio of length of the wall $(l)$, to the greater clear height $(h)$, of the openings adjacent to the wall, may not be less than its minimum value: $\min (l / h)=0.4$ for unreinforced masonry (with other type of units other than stone) and 0.3 for confined masonry.

Regarding the additional requirements for confined masonry, vertical confining elements should be placed at both sides of any wall opening with an area of more than $1.5 \mathrm{~m}^{2}$. It was shown that in the case of in-plane loading, 
confining elements contribute significantly to the overall capacity and the behaviour (Radnić et al. 2012; Penava et al. 2018).

\section{RELATIONS BETWEEN ARCHITECTURAL AND ENGINEERING CONCEPTS}

Eurocode 6 (CEN 2005) and 8 (CEN 2004) provide engineering guidelines for structural design. The comparison of architectural and engineering concepts can define a competent masonry infilled frame with openings. In hindsight, it would allow definition of not just the aspect ratio parameters regarding the full, partial or non-existing masonry infilled frames; but also, when does the infilled frames act as engineered or nonengineered structure due to shear loads.

The first step was to define the relations between the aspect ratio of each infilled wall regarding the window length. For this case the starting point was set at a height of $2.5 \mathrm{~m}$ as recommend by Neufert and Neufert (2012) to $4.5 \mathrm{~m}$. After that, the relation of the aforementioned height to the minimum distance of the wall with openings $(h / 5)$ was done; then, by selecting each opening length recommendation from Figure 1 resulted in an aspect ratio mesh of opening length which is presented in the Figure 5 and presents the boundaries for the windows.

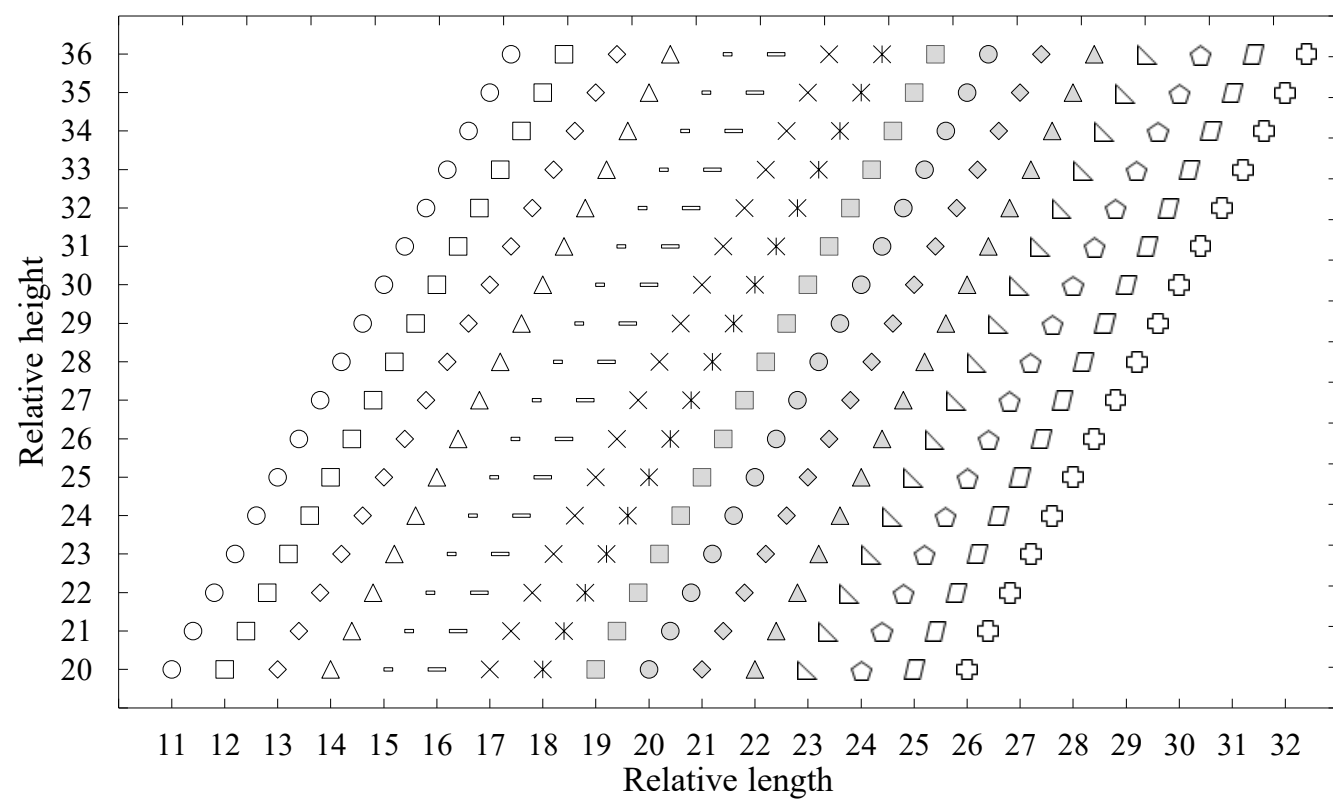

Figure 5. Aspect ratio mesh by window length (RL)

The next step is to create an aspect ratio for doors and then define the boundaries for a full or partial masonry infilled wall with openings.

For the case of window's aspect ratio, the tendency is to have a wide range, namely, values ranging between 0.17 and 6.55. However, Neufert and Neufert, (2012) recommend that the aspect ratio is limited from the value of 0.4 to 2.35 , whilst, most of them range from 0.4 to 1.57 .

Similarly, for the value of window's area, the tendency is also to have rather wide spectrum, ranging from 0.14 to $5.10 \mathrm{~m}^{2}$. Again, Neufert and Neufert, (2012) recommend the area of the openings from 0.14 to $3.39 \mathrm{~m}^{2}$. Where the upmost range from 0.14 to 2.74 . This means that a part of the recommended opening sizes need vertical confining elements (CEN 2004). The area relations within the engineering codes and architectual guides are presented in Figure 6.

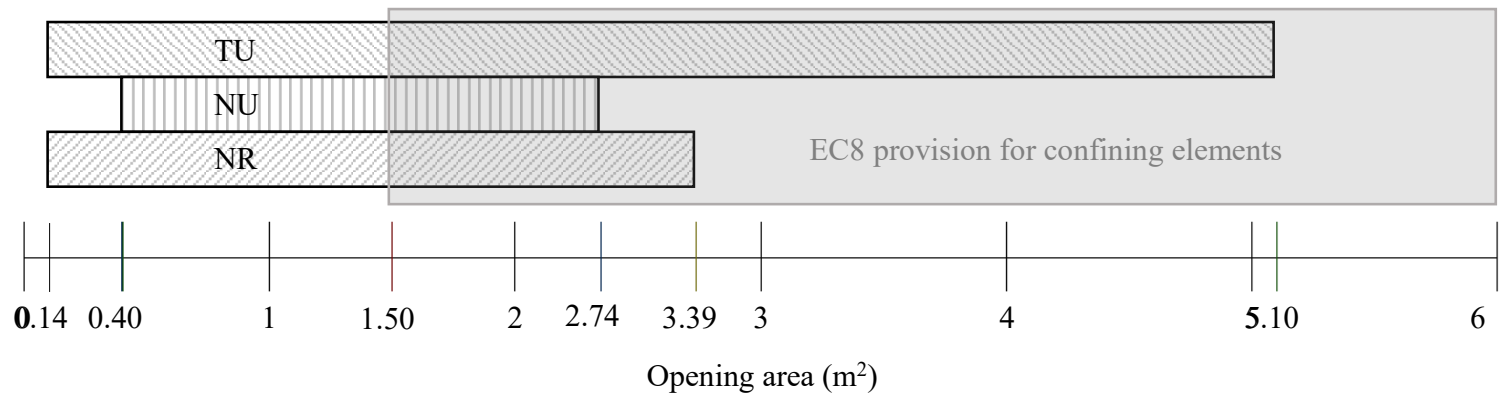

Figure 6. Area of window opening (TU - Typically Used, NR - Neufert Recommendations, NU - Neufert Upmost recommended, EC8 - Eurocode 8) 


\section{CONCLUSIONS}

In seismic regions throughout the world, commonly used structural system of multi-storey building are reinforced concrete frames that are usually infilled with some kind of masonry wall. Those masonry walls can contain one or more openings.

In the scientific literature, it is known that both infills and openings affect the overall seismic behaviour of infilled frames. They contribute to overall stiffness, failure modes, capacities, deformation capabilities etc.

Hence, there is a need to unite both architectural and engineering design in terms of opening type, size and placement. Conjointly, this paper reviewed various seismic codes in terms of infilled frame design with the incursion of openings, along with architectural design guidelines. It could be noted that there are wide discrepancies between themselves in regard to the effects of the openings and the incursion of infilled walls in the analysis. Furthermore, from the lack of regulations regarding infill walls, the load-bearing wall, i.e. engineered masonry provisions were consulted.

By combining both the architectural and engineering regulations and recommendations, guidelines and limitations are derived. Those can be used to derive modelling criteria and to define modelling parameter for aspect ratio of walls and openings that works for both architectural and engineering purposes.

\section{REFERENCES}

Akhoundi F, Vasconcelos G, Lourenco P, Silva L (2016) Out-of-plane response of masonry infilled RC frames : Effect of workmanship and opening. In: Modena, C., F., da P., Valluzzi, M.R. (Eds.), 16th International Brick and Block Masonry Conference. CRC Press/Balkema, Padova, Italy, 1147-1154

ASCE - American Society of Civil Engineers (2000) FEMA 356 Prestandard and Commentary for the Seismic Rehabilitation of Building

Asteris PG, Cotsovos DM, Chrysostomou CZ, Mohebkhah A, Al-Chaar, GK (2013) Mathematical micromodeling of infilled frames: state of the art. Eng. Struct. 56:1905-1921

ATC (1998) Evaluation of earthquake damaged concrete and masonry wall buildings: basic procedures manual (FEMA 306). Redwood City, California

BSI (2015) BS 4787-1:1980 | Internal and external wood doorsets, door leaves and frames. Specification for dimensional requirements

CEN (2004) Eurocode 8: Design of Structures for Earthquake Resistance - Part 1: General Rules, Seismic Actions and Rules for Buildings (EN 1998-1:2004). European Committee for Standardization, Brussels

CEN (2005) Eurocode 6: Design of masonry structures - Part 1-1: General rules for reinforced and unreinforced masonry structures (EN 1996-1-1:2005). European Committee for Standardization, Brussels

Cetisli F (2015) Effect of openings on infilled frame stiffness. J. Croat. Assoc. Civ. Eng. 67

Di Trapani F, Macaluso G, Cavaleri L, Papia M (2015) Masonry infills and RC frames interaction : literature overview and state of the art of macromodeling approach. Eur. J. Environ. Civ. Eng. 19

Dowrick DJ (2009) Earthquake Resistant Design and Risk Reduction, 2nd ed, Wiley Online Library: Books CN - 2009008862. John Wiley \& Sons Ltd

FEMA-P-749 (2010) Earthquake-Resistant Design Concepts: An Introduction to the NEHRP Recommended Seismic Provisions for New Buildings and Other Structures. Washington, DC

Kakaletsis DJ, Karayannis CG (2008) Influence of masonry strength and openings on infilled R/C frames under cycling loading. J. Earthq. Eng. 12, 197-221

Neufert E, Neufert P (2012) Architects' data, 4th ed. Wiley-Blackwell

NRCC (2010) National Building Code of Canada. Ottawa

NZSI (2004) NZS 4230:2004 Design of reinforced concrete masonry structures. Wellington

Penava D, Sarhosis V, Kožar I, Guljaš I (2018) Contribution of RC columns and masonry wall to the shear resistance of masonry infilled RC frames containing different in size window and door openings. Eng. Struct. 172:105-130

Radnić J, Harapin J, Smilović M (2012) Influence of vertical tie columns on bearing capacity of masonry walls. J. Croat. Assoc. Civ. Eng. 64:271-284

Schwarz J, Abrahamczyk L, Leipold M, Wenk T (2015) Vulnerability assessment and damage description for R.C. frame structures following the EMS-98 principles. Bull. Earthq. Eng. 13:1141-1159

Sigmund V, Penava D (2014) Influence of openings, with and without confinement, on cyclic response of infilled R-C frames - An experimental study. J. Earthq. Eng. 18

Wang C (2017) Experimental investigation on the out-of-plane behaviour of concrete masonry infilled frames. Dalhousie University 